\title{
DEGRADATION OF SURF-FISH FORAGING HABITAT DRIVEN BY PERSISTENT SEDIMENTOLOGICAL MODIFICATIONS CAUSED BY BEACH NOURISHMENT
}

\author{
Lisa M Manning, Charles H Peterson, and Stephen R Fegley
}

\begin{abstract}
Novel wave-tank mesocosms allowed hydrodynamically realistic tests of how sediment modifications affect feeding by a surf fish, Florida pompano, Trachinotus carolinus (Linnaeus, 1766). Pompano demonstrated visually based selection, preferentially preying on bean clams, Donax variabilis Say, 1822, colored in contrast with background. Pompano often took shell into their mouths instead of live bean clams. Sediments of nourished Bogue Banks (North Carolina) beaches exhibited $>2.5$-yr persistence of elevated coarse shell content at levels that suppressed pompano feeding in wave tanks. Elevated turbidity 4-8 mo after nourishment indicated that wave-induced erosion of buried fine sediments in sacrificial beach fill resulted in repeated turbidity events, reaching levels that in wave tanks reduced pompano feeding on Donax and mole crabs, Emerita talpoida (Say, 1817). Burial speeds of these prey in the beach swash zone were progressively reduced by increasing shell concentrations. Reduced burial rates reduce feeding opportunity and expose these mobile invertebrates to greater risk of wave transport out of the swash-zone habitat. Sampling six beaches revealed that density of Donax decreased linearly with increasing sediment size and shell concentration. Beyond the immediate mass mortality of invertebrate prey caused by $>1 \mathrm{~m}$ of sediment deposition during beach filling, coarse shell fragments and other large particles persist as a press disturbance for years after the nourishment ends, and elevated silts/clays can become resuspended by erosive wind events in repeated pulse disturbances for at least months afterward, in each case reflecting demonstrable long-term degradation of sandy-beach foraging habitat for surf fish.
\end{abstract}

The investigation of animal-sediment relationships affecting marine invertebrates has a long history (e.g., Sanders 1958, Rhoads and Young 1970, Johnson 1971, Snelgrove and Butman 1994), often shaped by interests of invertebrate paleoecologists (e.g., Stanley 1970, Kranz 1976, Alexander et al. 1993). On sandy ocean beaches, numerous studies have shown that the sedimentary habitat, as determined by tidal and wave forcing as well as availability of sediment types, influences the abundance, diversity, and taxonomic composition of benthic macroinvertebrates (e.g., Defeo and McLachlan 2005, McLachlan and Dorvlo 2005). The 1996 passage of the US Magnuson-Stevens Fishery Conservation and Management Act, which requires identification and protection of Essential Fish Habitat for species under federal management, has led to intensified research relating bottom habitats to use by demersal fishes (e.g., Peterson et al. 2000). Foraging value of sedimentary habitats to demersal fishes, crabs, and shrimps can be affected indirectly by sediment character, as granulometry and mineralogy influence abundances of benthic invertebrate prey. Yet sedimentology may also influence habitat use by demersal fishes directly. Experimental demonstrations of how addition of coarse sand to the surface of mud flats interferes physically with prey capture by the bills of probing shorebirds (Quammen 1982) and a 
recent analysis of selective shorebird foraging use of alternative ocean-inlet tidal-flat habitats (VanDusen et al., UNC, Inst of Marine Sciences, unpubl data) have revealed that sedimentology influences shorebird habitat use both indirectly through its effects on abundances of benthic invertebrate prey and also directly through armoring effects of coarse sand and shell that can block access by probers to buried (infaunal) prey. These demonstrations that multiple interaction pathways affect shorebird foraging choices serve to motivate analogous interdisciplinary studies of how benthic habitat variation may determine foraging value for predatory demersal fishes.

For the research reported here, we exploited beach nourishment (addition of sacrificial fill material) in North Carolina as a large-scale experiment to provide field tests of the nature and temporal duration of impacts to sandy-beach sedimentology and their effects on burial behavior of two dominant species of swash-zone macrofauna. Specifically, we conducted field trials in the swash zone of a sandy beach to determine how sediment size and shell hash influence burrowing rates of small and large bean clams, Donax variabilis Say, 1822, and mole crabs, Emerita talpoida (Say, 1817), the two biomass dominants on southeast Atlantic and Gulf coast beaches (Greene 2002). Then we linked quantitative measurements of mismatched sediments persisting after beach nourishment to the design of appropriate treatments in on-shore wave tanks that recreate physical hydrodynamic conditions of the swash zone of ocean beaches. Experiments tested the effects of increasing concentrations of shell fragments in the swash-zone feeding habitat of an iconic surf fish of the southeast coast, the Florida pompano, Trachinotus carolinus (Linnaeus, 1766), on its predation rate on Donax. We quantified surf-zone turbidity on nourished and undisturbed control beaches months after a beach-nourishment project that used fill material that included more fine sediments than are characteristic of the undisturbed control beaches. These surf-zone turbidity levels documented on the nourished beaches guided choices of turbidity treatments in wave-tank experiments testing effects on pompano feeding rates on Donax and mole crabs by changing turbidity levels. Finally, we sampled on a neighboring, never-nourished barrier island to determine how density of Donax varies naturally with coarse shell content in beach sediments to infer equilibrium consequences of persistently elevated shell-hash content.

The ocean beach shoreline habitats represent the front lines of policy and management struggles against impacts of climate change. In perhaps no other habitats are the joint consequences of sea-level rise and increased incidence of intense storms a more evident threat (Dugan et al. 2010). The long history of coastal barrier-beach persistence during millennial variations in sea-level stand implies that this habitat is highly resilient to such major environmental changes, but when people act to protect development on coastal barriers and thereby intervene in natural processes of barrier-island transgression, the beach ecosystem's integrity is compromised (Schlacher et al. 2008, Defeo et al. 2009). We explored the ways that one management approach intended to prevent transgression of coastal barriers, beach nourishment, influenced habitat use by and value for surf fishes.

\section{Methods}

Sedimentological Habitat Changes after Beach Nourishment.-Peterson et al. (2006) characterized sedimentological modifications from a 2001-2002 beach-nourishment project on Bogue Banks, North Carolina, covering $11 \mathrm{~km}$ from Pine Knoll Shores to Indian 

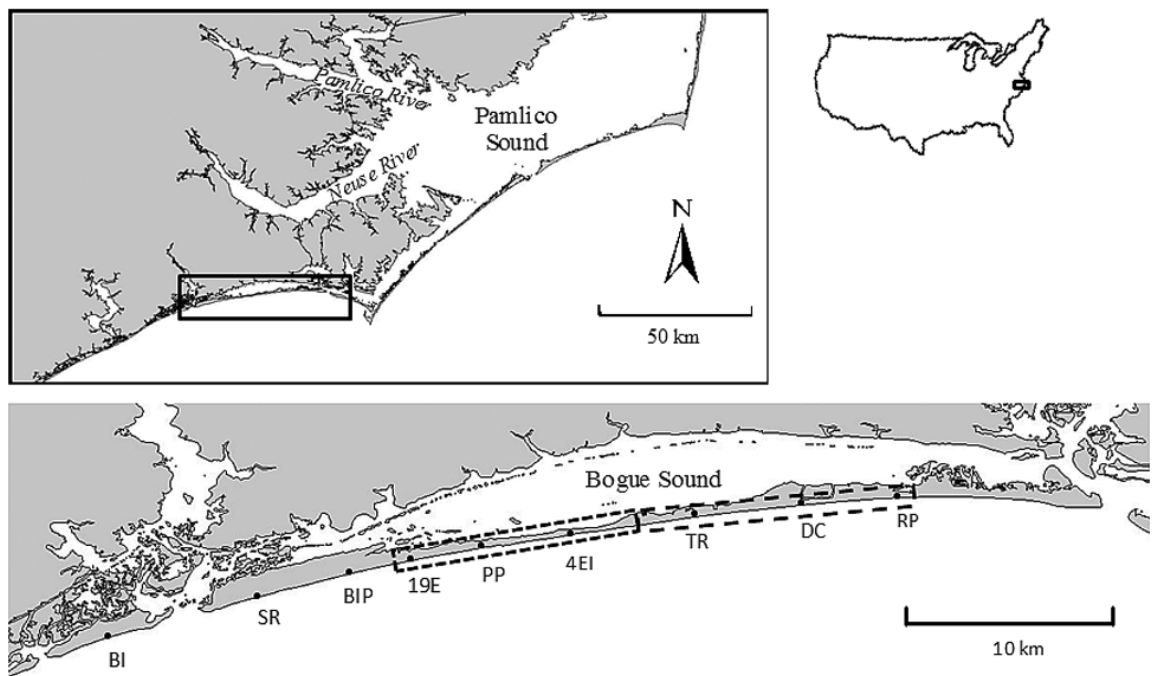

Figure 1. Map of the North Carolina coast showing study sites sampled for estimation of sedimentary effects of Bogue Banks nourishment Phase I in 2002, 2003, and 2004, and Phase II in 2003 and 2004. Spatial extents of Phase I and Phase II nourishments are indicated by the largedashed and small-dashed rectangles, respectively. Study sites were BI, Bear Island (Phase I and II control); SR, Spinnaker's Reach (Phase I and Phase II control); BIP, Bogue Inlet Pier (Phase II control); 19E, 1911/1913 Emerald Isle (Phase II nourished); PP, Pierpoint (Phase I control and Phase II nourished); 4EI, 4th St. Emerald Isle (Phase II nourished); TR, Trinity Center (Phase I nourished); DC, Dogwood Circle (Phase I nourished); and RP, Royal Pavillion (Phase I nourished). The western tip of Shackleford Banks is visible at the right margin of the map showing study-site locations.

Beach (Fig. 1), referred to as the Bogue Banks Phase I nourishment. Data presented included sediment size distributions in five beach zones along vertical transects from the toe of the primary dune to a depth of $1 \mathrm{~m}$ at low tide on three replicate filled and three control beaches on three dates after the March-April 2002 completion of the project-March, July, and November 2002. Also described in that publication are data taken in July 2002 from replicate $0.25-\mathrm{m}^{2}$ weighted PVC quadrats haphazardly placed in two beach zones, the mid-intertidal (persistently wetted) and the swash zones, on visual characterization of the percentage surface cover by shell and shell hash on the same set of replicated filled and control beaches. We extended the time frame of sedimentological sampling to November 2003 and July 2004 by measuring sediment size distributions using sampling and analytic methods identical to those described by Peterson et al. (2006). During these second and third years' postnourishment samplings, we used the same set of three nourished beaches (Royal Pavilion, Dogwood Circle, and Trinity Center). We used two of the original control beaches (Spinnaker's Reach and Bear Island), but the third control site (Pierpoint) was nourished in April 2002, so we substituted a new control, Bogue Inlet Pier, for 2003 and 2004 samplings (Fig. 1). At each beach, three vertical transects $40 \mathrm{~m}$ apart were sampled at each of two sites (east and west, separated by $150 \mathrm{~m}$ ). We also repeated the visual assessment of surface shell cover in the mid-intertidal and swash zones on the same set of nourished and control beaches in July 2004, long after nourishment was completed.

Here we also present data from the second Bogue Banks beach-nourishment project (called Phase II), which applied fill to another $18 \mathrm{~km}$ in Emerald Isle between November 2002 and April 2003 (Fig. 1). Like the sampling done for Phase I, our assessment of the impacts of filling and its temporal duration on sediment size distributions involved three randomly chosen replicate beaches that received fill and three control beaches. Nourished beaches were 
Emerald Isle at 4th St., 1911/1913 Emerald Isle, and Pierpoint; control beaches were the same three listed above. The transect sampling design used in Bogue Banks Phase II was identical to that employed in Phase I; sampling was conducted in November 2003 and July 2004. Following recommendations in James and Fairweather (1996) for sandy-beach inferences, we determined significant differences $(P<0.05)$ between nourished and control treatments separately for each sampling date and sediment size class by three-factor ANOVAs with treatment (nourished and control), beach (three levels nested within treatment), and site (two levels, east and west, nested within beach) done on arcsin-transformed proportions pooled over all five elevation zones. Surface shell cover was also estimated in July 2004 in the mid-intertidal and swash zones of both sites of all beaches associated with both the Phase I and Phase II assessment designs, again by methods identical to those described by Peterson et al. (2006). Surface shell-cover data were analyzed after arcsin transformation of proportions pooled over the two elevation zones sampled, by three-way ANOVA with treatment (nourished and control), beach (three levels nested within treatment), and site (two levels, east and west, nested within beach).

Delayed Episodic Effects of Beach Nourishment on Turbidity along Shore.Silts and clays that are deposited on high-energy ocean beaches can be mobilized and transported by waves that strike the beach with sufficient force to erode sediments. Silts and clays are fine enough that, in accord with Stokes's law (which describes how settlement rates of suspended particles increase with particle size), they can remain suspended in the water column for hours to days, creating persistent near-shore turbidity. If beach fill includes a high percentage of silts and clays, episodic erosion into that fill material could result in repeated suspension of newly exposed fine sediments in the eroding beach long after the dredge-andfill project has been completed. The primary intent of beach nourishment is to create a sacrificial sediment mass on eroding beaches so that wave action, especially during major storms like hurricanes, becomes dissipated by eroding the dredged materials instead of eroding the primary dune and damaging beachfront houses and infrastructure. Consequently, the induction of near-shore turbidity can in principle recur during the entire life span of the nourishment project as new dredged materials are progressively exposed and their unnaturally muddy sediments create temporally persistent turbidity.

As tests of this anticipated process, we conducted two separate "experiments" using turbidity sampling on replicate Phase I nourished and control beaches to determine whether erosive wind events induced different levels of turbidity as a function of nourishment. We first sampled on 1 July, 2002, a date chosen on the basis of a 36-hr relief from $5 \mathrm{~d}$ of wave generation by persistent southerly (S) to west-southwesterly (WSW) onshore winds. Bogue Banks is a south-facing beach (Fig. 1), so such winds blow onshore and generate erosive wind waves, whereas northeasterly (NE) winds blow offshore and smooth the water's surface near shore. Daily mean wind speeds and directions were as follows: 25 June, WSW $4.0 \mathrm{~m} \mathrm{~s}^{-1}$; 26 June, SW $5.4 \mathrm{~m} \mathrm{~s}^{-1}$; 27 June, SW $7.2 \mathrm{~m} \mathrm{~s}^{-1}$; 28 June, SW $8.0 \mathrm{~m} \mathrm{~s}^{-1}$; 29 June, WSW $4.5 \mathrm{~m} \mathrm{~s}^{-1}$; 30 June, NNE $4.0 \mathrm{~m} \mathrm{~s}^{-1}$; 1 July, NNE $4.0 \mathrm{~m} \mathrm{~s}^{-1}$ (National Weather Service, Newport, NC). Our second experiment involved sampling for $3 \mathrm{~d}: 20,21$, and 23 August. 20 August was the last of three successive days of S-WSW (onshore) winds, averaging 4.5-6.3 $\mathrm{m} \mathrm{s}^{-1}$, whereas this pattern switched to NNW on 21 and 22 August, only returning to onshore on the afternoon of 23 August. Daily mean wind speeds and directions were as follows: 18 August, WSW $6.3 \mathrm{~m} \mathrm{~s}^{-1}$; 19 August, SW $4.5 \mathrm{~m} \mathrm{~s}^{-1}$; 20 August, WSW $4.7 \mathrm{~m} \mathrm{~s}^{-1}$; 21 August, NNW $5.1 \mathrm{~m} \mathrm{~s}^{-1}$; 22 August, NNW $2.7 \mathrm{~m} \mathrm{~s}^{-1}$; 23 August, WSW $5.8 \mathrm{~m} \mathrm{~s}^{-1}$. Our August sampling was thus planned to document the temporal dynamics from the expected peak of fine sediment suspension at the end of a typical 3-d stretch of summer onshore winds through the following $3 \mathrm{~d}$ of calm conditions after wavegenerating winds had abated. The three nourished beaches were filled in early December 2001 (Royal Pavilion), early February 2002 (Dogwood Circle), and April 2002 (Trinity Center). Control beaches used for this study were Pierpoint, 1911/1913 Emerald Isle, and Spinnaker's Reach (Fig. 1). Although the pattern of nourishment did not allow interspersion of treatment 
and control beaches, interviews with surfers supported our observations that wave conditions do not vary along this stretch of Bogue Banks under persistent $\mathrm{S}$ to WSW winds.

Our two turbidity "experiments" differed in duration and in location(s) of water sampling. To sample for turbidity, we collected five replicate water samples by sequentially filling, washing, and refilling a plastic bottle at each beach at a single depth of $0.5 \mathrm{~m}$ in the surf zone on 1 July and at two locations relative to the waterline for each of the $3 \mathrm{~d}$ in August: at the same 0.5 - $\mathrm{m}$ depth in the surf zone and at 1.5 -m depth farther offshore, just inside the outer sand bar. After its transport to shore, each sample was shaken, then injected into a clean turbidity-meter sampling jar, and the turbidity value in nephelometric turbidity units (NTUs) read after $8 \mathrm{~s}$. This entire process was completed successively on each beach during a single morning low tide. Sampling was conducted at an eastern site and $150 \mathrm{~m}$ away at a western site on each beach, within each of which the five replicate water samples were taken $40 \mathrm{~m}$ apart along the beach. Turbidity readings on 1 July were analyzed by a one-way ANOVA with beach treatment as a fixed factor. August turbidity readings were analyzed by a repeated measures (date) two-way factorial ANOVA with water depth and beach treatment as fixed factors and with individual beaches nested within beach treatment. All values were power-transformed to preclude significant departure from homogeneity of variance as confirmed by Cochran's test.

Effects of Sediment Coarseness on Burrowing Rates of D. variabilis and E. TALPOIDA ON THE BEACH.-In August 2003, we conducted experimental tests of the effects of changing sedimentology on burial speeds of both D. variabilis and E. talpoida, using two size classes of each. These two species are the greatest contributors to the total biomass of sandy beach infauna in North Carolina and likewise serve as the dominant prey for pompano (C Peterson pers obs). Our tests consisted of timed burial trials for individual D. variabilis and E. talpoida freshly collected on the Atlantic Beach, North Carolina, strand. Trials were standardized within a metal cylinder $30 \mathrm{~cm}$ in diameter and $25 \mathrm{~cm}$ high used as an experimental arena, which we inserted $15 \mathrm{~cm}$ into the sediments in the swash zone and in which we maintained a water cover of at least $2 \mathrm{~cm}$. Before introducing the animals, we replaced the top $15 \mathrm{~cm}$ of sediments inside the cylinder with different sediment mixtures. Sediments may therefore have been less compacted by this process of replacement with sieved sediments and therefore have increased burial rates, but additions occurred for each treatment, so treatments should not differ in this respect. For one set of assays, we used stacks of sieves to sort ambient beach sands from (frequently nourished) Atlantic Beach into five size classes, from 0.0625 to $>4 \mathrm{~mm}$ (very fine sand, medium sand, coarse sand, gravel, pebble) and also included a 6th treatment representing the full range of sediment sizes in the unsorted beach sediments (with a median of $0.177 \mathrm{~mm}$ ). For another set of assays, we combined ambient, unsorted beach sands mixed in different portions with shell hash ranging in size from coarse sand to pebble sizes ( 2 to $>4$ $\mathrm{mm}$ ) so as to construct "dilution curves" like a pollutant bioassay, describing burial rates for each species as a function of changing ratio by volume of sand to shell. We again included a sediment treatment of unmodified beach sands with a median size of $0.177 \mathrm{~mm}$ and trivial levels of shell hash, $<3 \%$ by dry weight. The two size classes used for D. variabilis and E. talpoida were large (1.5-2.0 cm SL, $n=10$, and $1.5-2.0 \mathrm{~cm} \mathrm{SL}, n=30$, respectively) and small $(0.5-0.8 \mathrm{~cm} \mathrm{SL}, n=20$, and $0.5-1.0 \mathrm{~cm} \mathrm{SL}, n=30$, respectively). Each animal, individually introduced, was used only once and removed before the next was tested. Stopwatch timing began when the organism first began digging and ended upon shell (carapace) disappearance. Burrowing times to complete burial for Donax were log-transformed and for Emerita power transformed for homogenization of variances, as confirmed by Cochran's tests, and then analyzed by two-way ANOVA with size and sediment composition as fixed factors. Multiple comparisons among sediment-shell treatments were determined by Tukey contrasts. For all four analyses, Tukey's test was used for the a posteriori comparisons (Day and Quinn 1989).

Relationship between Shell Content of Swash-Zone Sediments and Donax AbundanCE ON NATURAL BEACHES.-During June 1997, we sampled six beaches haphazardly 
scattered at 1.8-3.0 km intervals over $15 \mathrm{~km}$ of Shackleford Banks (part of Cape Lookout National Seashore), while remaining at least $0.5 \mathrm{~km}$ from inlets, to determine how Donax spp. density varied with sediment grade and especially with shell content of surface sediments. Although Donax spp. were not resolved by species, D. variabilis consistently formed over $96 \%$ and Donax parvula Philippi, $1849^{1}<4 \%$ at all sites, beaches, and dates sampled by Manning (2003). We sampled at low tides along three replicate vertical transects at each beach, spaced at $50-\mathrm{m}$ intervals. Transects involved core sampling every $3 \mathrm{~m}$ from the toe of the primary dune to $1 \mathrm{~m}$ depth in the surf zone; each sample comprised two adjacent cores taken with the same core tubes $\left(82 \mathrm{~cm}^{2}\right)$, sample depth $(15 \mathrm{~cm})$, and sieve mesh $(1.0 \mathrm{~mm})$ used by Peterson et al. (2006) to sample infaunal Donax. We also took sediment cores $(4.8 \mathrm{~cm}$ diameter) to 10 $\mathrm{cm}$ depth: three stratified random cores were pooled to form a sample from each intertidal and subtidal beach zone (high intertidal dry sand, mid-intertidal wet sand, swash, and shallow subtidal surf), for which we analyzed grain-size distribution using the methods described by Peterson et al. (2006). Visibly detectable shell fragments occurring in the gravel (defined here to include all granule sizes $>2 \mathrm{~mm}$ ) and coarse-sand (between 0.5 and $2.0 \mathrm{~mm}$ ) classes were isolated during sieving and weighed. This sampling and analysis produced sediment size distributions, from which we computed mean grain size and average percent shell content by weight at each beach. We then tested for relationships between density of Donax on natural unmodified beaches and mean sediment grain size and separately concentration of shell hash in surface sediments, into which Donax must repeatedly burrow as it migrates up and down the beach with each flooding and ebbing tide. Results were analyzed by separate linear regressions: one regressing mean abundance of Donax per transect (the sum of all samples on the transect) on mean grain size of each beach in the four zones occupied by Donax and the other regressing mean abundance of Donax per transect on mean percentage by weight of shell for each beach.

Effects of Sediment Shell Content on Florida Pompano Feeding Rates.Feeding-rate assays were conducted in specially designed wave-tank mesocosms, which we created from open-topped rectangular stainless-steel tanks located at the University of North Carolina Institute of Marine Sciences to simulate surf and swash-zone physical conditions (Fig. 2). Each of the 16 tanks was $2 \mathrm{~m}$ long, $1.2 \mathrm{~m}$ wide, and $0.6 \mathrm{~m}$ deep. Periodic waves were generated by the continuous filling of an asymmetric wooden trough on wooden dowel hinges located at one end of each tank. As a continuous flow of unfiltered seawater from nearby Bogue Sound filled each trough, its asymmetry led to instability, sudden rapid rotation, and water dumping, producing a visible surface wave that propagated to the opposite end of the tank (Fig. 2). Flow to each trough was adjusted to achieve the same wave-generating rate (one wave every $30 \mathrm{~s}$ ). Each tank was partially filled with beach sand, which we sloped to create a deeper ("subtidal") basin at the trough end and a shallow swash ("intertidal") zone at the other end that simulated physics of oscillatory flow of breaking waves in the swash-zone habitat on a sandy ocean beach. Individual fish were randomly assigned to tanks and allowed to acclimate for $48 \mathrm{hrs}$ before each experiment began. Fish were fed cut shrimp daily and again lightly fed $1 \mathrm{hr}$ before use. To initiate a predation assay, we haphazardly scattered individual $D$. variabilis within the "swash" areas of the tanks. Because pompano are attracted to human hands and react to the presence of an observer, a piece of Vexar mesh was used to fence the fish temporarily out of the swash area until all prey had been placed.

Experimental sediment treatments within the swash-zone feeding area involved natural beach sands with median grain size of $0.177 \mathrm{~mm}$ plus a set of three mixtures of that sand with shells and shell hash (shell pieces 2.0 to $>4.0 \mathrm{~mm}$ in size sorted from a nourished beach). Shell-to-sand ratios by volume were $0: 1,1: 1,2: 1$, and 4:1. Each experimental tank was modified to serve as a single replicate of each sediment mixture or control (natural beach sand alone) to a depth of $5 \mathrm{~cm}$ throughout the swash zone. Each of the four sediment types was

1 A minority of authors have used Donax parvulus and others have questioned the validity of both Donax parvula and Donax parvulus. Competent taxonomic authorities need to resolve the confusion associated with the appropriate name for this distinct species. 


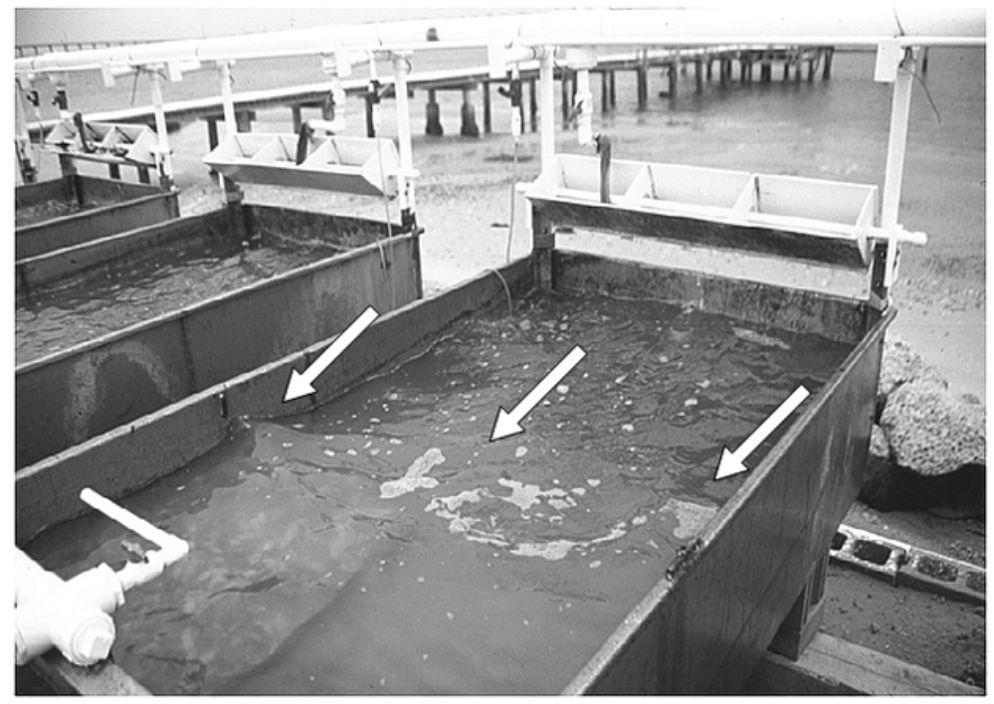

Figure 2. Wave-tank mesocosm, in which a surface wave is visible (indicated by white arrows). Such waves were periodically generated by water released when the continuously filled asymmetrical white trough overbalanced and dumped its contents; they progressed to the shallow swash zone of upward sloping beach sands in the foreground of the photograph.

replicated in four separate tanks; one treatment was assigned to one tank at random within each of four spatially contiguous blocks. Twelve Donax $(0.8-1.2 \mathrm{~cm} \mathrm{SL})$ were offered to each fish (8.0-11.0 cm TL), and the number of Donax consumed during a 5-min feeding period was recorded. From previous experience, we knew that this time would be sufficient to allow consumption of approximately $30 \%-70 \%$ of prey items. This procedure was repeated twice, each time with naive fish and fresh prey, to produce eight replicates of each sediment type. No effect of block or day was detected, so these variables were removed from the analysis, and numbers of Donax consumed in each sediment type were analyzed in a one-way ANOVA after we confirmed homogeneity of variances with Cochran's test. Pairwise comparisons were made with Scheffé's test.

Effects of Background Shell Color on Predator Preference for Shell Color of DONAX.-As sandy-beach sediments are modified by beach nourishment to include increasing amounts of surface shell, selection of prey color morphs could change. We used the wave-tank mesocosms to test for effects of the surface presence of differently colored shells and shell fragments on the choice between Donax colored to match the shells and Donax with contrasting shell color. We chose to compare the white and the grayish purple Donax shell colors, the two most abundant color morphs on Bogue Banks (Manning 2003). We conducted identical feeding-choice experiments on two different predators, the Florida pompano, which appears to be a visual predator, and the speckled crab, Arenaeus cribrarius (Lamarck, 1818), another known consumer of Donax on sandy ocean beaches in North Carolina (Leber 1982), which is suspected of using chemical or tactile detection in prey selection.

Within the swash-zone area of $60 \times 30 \mathrm{~cm}$ in each of eight tanks, we haphazardly placed 30 pieces of shell $30-70 \mathrm{~mm}$ in length and irregularly shaped, not chosen to match Donax shell shapes. Shell pieces in four tanks were white, and those in the other four were medium gray. Each color treatment was equally distributed among the four spatially defined blocks of tanks and assigned at random to specific tanks within blocks. In this set of pompano trials, we placed 10 Donax individuals ( 5 white and 5 grayish purple) in each tank and fully interspersed them throughout the swash zone. For this experiment, we glued the Donax valves shut so as to prevent burial and thereby sustain ability of visually orienting predators to respond to 
color. We then added a single pompano $(9.0-15 \mathrm{~cm}$ TL) to each tank and observed its feeding from a distance so that we could halt the trial when about half the prey had been consumed. Trials were repeated three times on a single day with fresh pompano and prey at each time. From these trial runs, we successfully produced 11 replicates of each shell-piece coloration treatment. Effect of surface shell-piece color on average numbers of white Donax eaten was analyzed by Poisson-based general linear model (GLM) after Cochran's test confirmed homogeneous variances. Analogous tests on consumption of grayish purple Donax yielded identical statistical conclusions and are not presented. A Wilcoxon signed-rank test was used to assess significance of pompano choice of Donax that did and did not match background color $(n=22)$.

For the analogous experiment, speckled crabs $(6.22-9.45 \mathrm{~cm}$ in carapace width) were maintained in 26 small plastic bins $(30 \times 29 \times 13 \mathrm{~cm})$ within a recirculating seawater system inside the laboratory building. Each bin held a 2-cm layer of beach sand. In addition, half held 15 pieces (30-70 mm long) of the same shell and shell fragments used in the pompano experiments; six held white shell only and 7 medium gray shell only. Treatments were assigned at random to individual bins. We placed sets of 20 Donax $(0.9-1.2 \mathrm{~cm} \mathrm{SL})$, again glued shut, 10 white and 10 grayish purple, haphazardly around each bin. Trials were ended after about half the Donax were consumed. After demonstration of homogeneity of variances with Bartlett's test, Poisson-based GLM was used to test for significant differences between sediment-shellcolor treatments in consumption of white Donax. A Wilcoxon signed-ranks test was used to test for significant differences in crab choice between Donax that did or did not match background shell color $(n=13)$.

Effects of Turbidity on Predation Rate by Pompano.-To determine whether turbidity influences feeding rate of pompano on either or both of its predominant prey, Donax and Emerita, we established experimental feeding trials within the wave-tank mesocosms. We raised the turbidity in experimental tanks by suspending kaolin clay particles in the raw seawater inside the head tank that gravity-fed water to the wave-tank troughs. Turbidity was measured repeatedly during each experimental trial. We re-established the water level and turbidity in the head tank twice every 24 hrs by periodic addition of kaolin and new seawater. We conducted 11 replicate trials with fresh, naïve pompano in each trial (11 turbidity replicates and 11 controls for Donax, and 5 turbidity replicates and 6 controls for Emerita). The Donax trials required $2 \mathrm{~d}$ to complete; equal numbers of turbid replicates and clear controls were run on each day. Weather conditions remained identical, and inspection of daily results revealed no difference between days. In each trial, we introduced a fixed number of prey into the swash-zone area (20 Donax $0.9-1.2 \mathrm{~cm}$ SL or 20 Emerita $1.5-2.0 \mathrm{~cm} \mathrm{SL}$ ) and allowed them to burrow into the sediments before introducing the single pompano and thereby beginning the feeding trial. The duration of trials was $1 \mathrm{hr}$ for Donax and $4 \mathrm{~d}$ for Emerita. In the Donax trials, we established average turbidities of 101 NTUs in treatment tanks and 9 NTUs in control tanks. For Emerita trials, the turbidities averaged 74 NTUs in treatment tanks and 7 NTUs in control tanks. We used $t$-tests on arcsin-transformed proportions of prey consumed to test for significant effects of turbidity on feeding rate of pompano, running separate tests for the two prey species.

\section{REsults}

Sedimentological Habitat Changes Following Beach Nourishment.Fill sediments used for Phase I of the Bogue Banks beach nourishment project, conducted from November 2001 to April 2002, differed dramatically from natural beach sediments on the Pine Knoll Shores beaches, which had never before been modified by fill. Specifically, Peterson et al. (2006) reported that gravel-sized shell hash averaged $9.8 \%$ by weight in surface sediments of nourished beaches but only $1.9 \%$ on 
control beaches, that coarse sand-sized particles dominated by shell were higher on nourished beaches (19\%) than on control beaches $(6 \%)$, and that silt/clay content was also higher on nourished beaches $(0.7 \%)$ than on control beaches $(0.4 \%)$ in averages across March, July, and November 2002 postnourishment surveys. Our new granulometry data from November 2003 and July 2004 revealed that the statistically significant pattern of elevated gravel- (ANOVA: 2003: $F_{2,23}=22.15, P<0.0001$; 2004: $\left.F_{2,23}=6.61, P<0.005\right)$ and coarse sand-sized (2003: $F_{2,23}=13.11, P<0.0002$; 2004: $\left.F_{2,23}=11.55, P<0.0003\right)$ particles in surface sediments of nourished beaches persisted for these two additional years without evidence of any convergence toward control levels (Fig. 3). Furthermore, sampling after Phase II of the Bogue Banks project, completed 1 yr after Phase I, revealed similarly increased levels of gravel-sized ( $>2 \mathrm{~mm}$ ) shell materials (17.5\% on filled beaches, $7.7 \%$ on controls) and coarse-sandsized $(0.5-2 \mathrm{~mm})$ shell particles (20\% filled, $14.6 \%$ control) on nourished beaches in November 2003, which persisted $(P<0.05)$ to the following July 2004, showing partial but incomplete convergence toward control levels (Fig. 3). Although significantly different in the July and November 2002 samplings by Peterson et al. (2006), the finest sediments did not continue to demonstrate a detectable difference between filled and control beaches on Phase I nourished beaches in our new sampling, years after the project ended, and likewise no difference in the silt-clay fraction was detectable between nourished and control beaches in the Phase II project (Fig. 3). Visual surveys of percentage surface shell cover averaged across the (persistently wet) midintertidal and swash zones revealed large and statistically significant (ANOVA: $F_{1,11}=$ 14.39, $P<0.0004$ ) elevation in shell cover on Phase I nourished beaches in July 2002. In July 2004, percentage shell cover was also significantly elevated on Phase I and II nourished beaches $\left(F_{2,9}=16.92, P<0.006\right)$; Phase I nourished beaches showed partial convergence toward control values 27-32 mo after project completion, and Phase II nourished beaches exhibited average surface shell cover 15-20 mo after project completion at levels similar to first-year levels in Phase I (Fig. 4).

Delayed Episodic Effects of Beach Nourishment on Turbidity Along SHORE.-Sampling on 1 July, 2002, after 36 hrs of NE winds averaging 9 mph (a period of relaxation from the preceding $5 \mathrm{~d}$ of persistently erosive on-shore $\mathrm{S}$ to WSW winds of 9-18 mph), revealed significantly higher average turbidities (ANOVA: $F_{1,40}$ $=139.2, P<0.0001$ ) by a factor of three on beaches nourished $3-7$ mo previously [mean of 106.8 (SE 3.8) NTUs] than on unmodified control beaches [36.8 (SE 4.6) NTUs]. Means exceeded the state of North Carolina's standard for allowable turbidity (25 NTUs) on both sets of beach sites. Analysis of 20-23 August turbidity samples taken 4-8 mo after nourishment documented the changes during relaxation of onshore winds and erosive waves, revealing significant effects of depth (ANOVA: $F_{1,96}=24.3, P<0.0001$ ), date (ANOVA: $F_{2,95}=957.6, P<0.0001$ ), beach nourishment (ANOVA: $F_{1,96}=609.6, P<0.0001$ ), and the interaction between date and nourishment (ANOVA: $F_{2,95}=409.9, P<0.0001$; Fig. 5). Turbidity again greatly exceeded the allowable North Carolina turbidity standard on 20 August; violations were larger on nourished beaches. Turbidity declined substantially from 20 to 23 August (Fig. 5) as offshore winds continued to maintain calm surf conditions. The decrease in turbidity after relaxation of wave forcing was more rapid on control beaches than on the nourished beaches (Fig. 5), causing the significant interaction between date and 

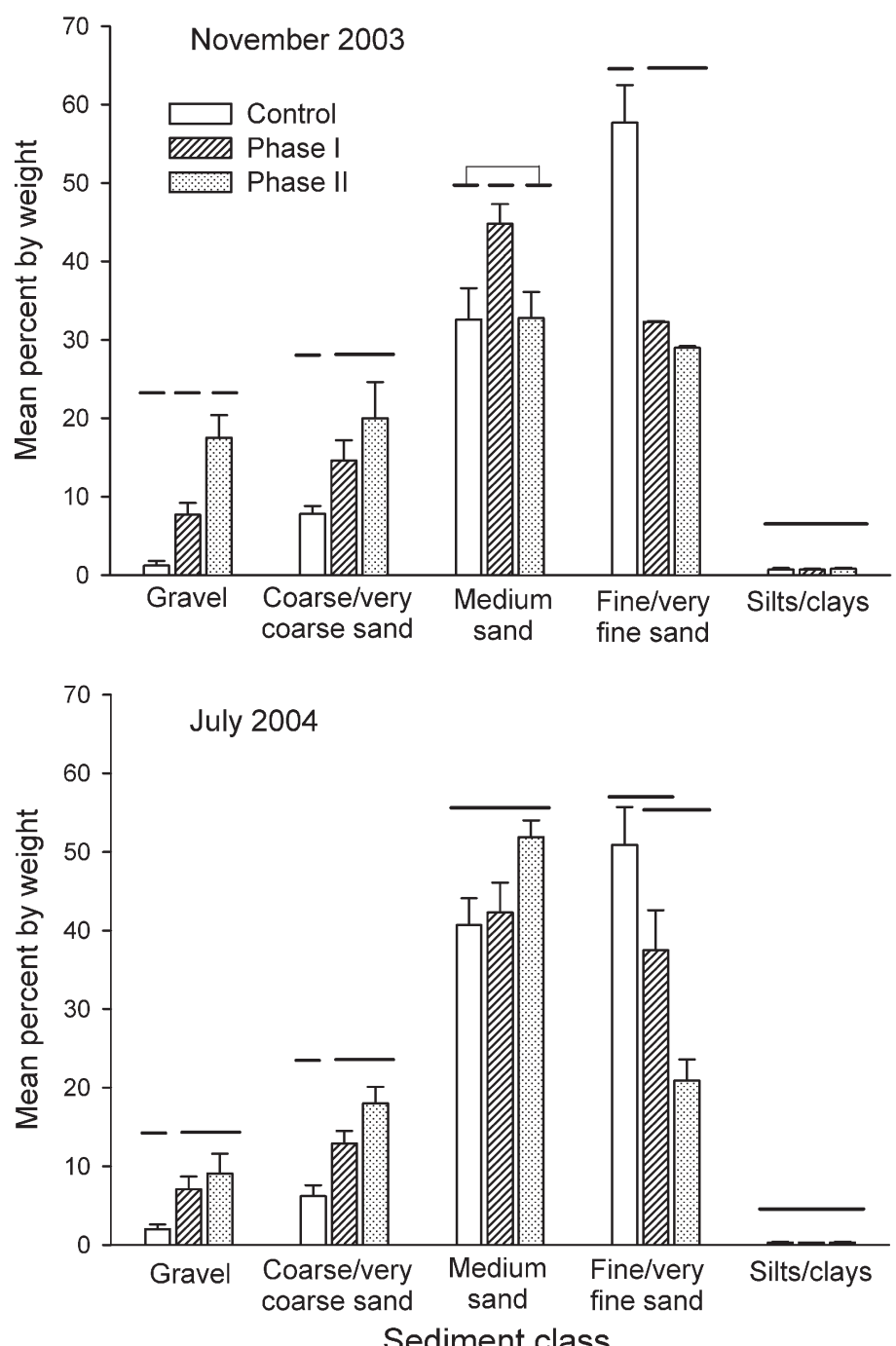

Figure 3. Granulometry of beach sediments, averaged from the top of the mid-intertidal zone to a depth of $1 \mathrm{~m}$ into the surf at low tide for Phase I nourished (November 2001-April 2002), Phase II nourished (November 2002-April 2003), and unmodified control beaches ( $n=3$ of each). Nonoverlapping horizontal lines indicate significant differences $(P<0.05)$ within sediment size classes among nourished and control treatments as revealed by Tukey unplanned comparisons after significance of treatment effects in nested ANOVAs. 


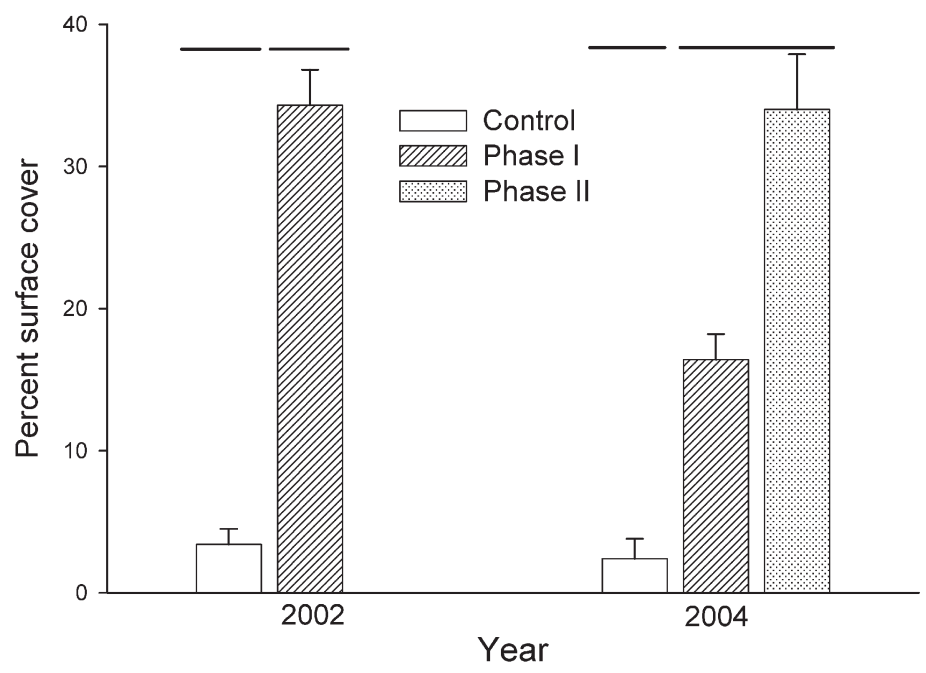

Figure 4. Mean percentage surface cover by visible shell in the mid-intertidal (always wet) and swash zones at low tide on Bogue Banks beaches sampled in July of both years after the November 2001-April 2002 Phase I project and in July 2004 after the November 2002-April 2003 Phase II project and on unmodified control beaches ( $n=6$ of each). Statistical tests and results as indicated in Figure 3.

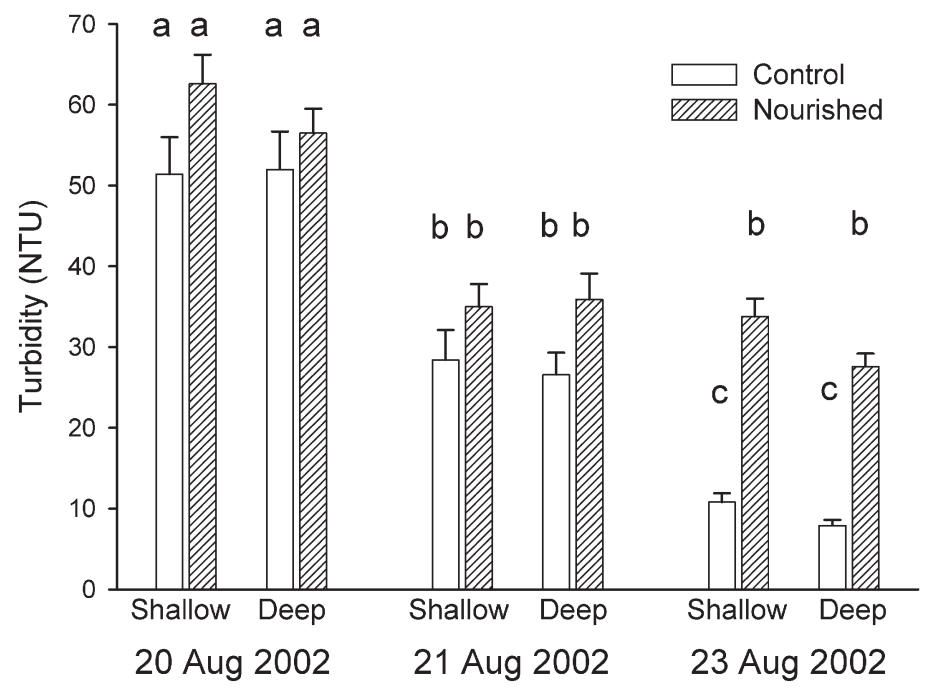

Figure 5. Mean turbidity in surf zones off beaches nourished 4-8 mo previously and off unmodified control beaches ( $n=3$ of each) during relaxation of a 5-d, erosive onshore wind event, ending with a shift to offshore winds during the night of 19 August, which persisted until the afternoon of 23 August. Means average shallow $(0.5 \mathrm{~m})$ and deep $(1.5 \mathrm{~m})$ water samples, of which five replicate subsamples were taken at each of two locations (east and west) on each beach. Different letters above the means indicate significant differences $(P<0.05)$ across dates, treatments, depths, and their interactions, as revealed by repeated measures ANOVA. NTU $=$ nephelometric turbidity unit. 
nourishment treatment. The water-depth effect was a consequence of slightly higher turbidity near shore, but depth did not interact with date or nourishment treatment.

Effects of Sediment Coarseness on Burrowing Rates of D. VARiabilis AND E. TALPOIDA ON THE BEACH.-Burial rates of D. variabilis and E. talpoida were significantly affected by changes in sedimentology. Two-way ANOVA revealed significant effects of Donax size $\left(F_{1,210}=108.4, P<0.0001\right)$, sediment size $\left(F_{5,210}=58.9, P\right.$ $<0.0001)$, and their interaction $\left(F_{5,210}=2.7, P=0.021\right)$ on burial times. The burrowing trials on two size classes of Donax in sediments sorted by sediment size classes from 0.0625 (fine sand) to $>4 \mathrm{~mm}$ (pebble sizes, composed of shell hash) demonstrated that burial times of large Donax remained constant from 0.0625 to $1 \mathrm{~mm}$, then were sharply higher for $2 \mathrm{~mm}$ sediment size and higher again at $>4 \mathrm{~mm}$ (Fig. 6). Small Donax likewise demonstrated a significant increase in burial times from 1 to $2 \mathrm{~mm}$ but no further increase from 2 to $>4 \mathrm{~mm}$ (Fig. 6). This difference at the largest sediment size class is the source of the significant interaction between sediment size and Donax size class (Fig. 6). Burial rates of both small and large Donax in natural beach sediments with a mean size of $0.177 \mathrm{~mm}$ corresponded to observed burial rates in the range of $0.0625-1 \mathrm{~mm}$. Observations of burrowing revealed that both small, and especially large, individuals were often prevented from successful burial by direct encounter with large shell fragments, requiring them to reorient digging to achieve burial.

Results of identical burial trials conducted on Emerita revealed patterns of response to sediment size that were nearly the same as those of Donax (Fig. 6). Two-way ANOVA revealed significant effects of crab size $\left(F_{1,348}=81.1, P<0.0001\right)$, sediment size $\left(F_{5,348}=63.9, P<0.0001\right)$, and their interaction $\left(F_{5,348}=3.1, P=0.0095\right)$. For both large and small size classes, burrowing time to complete burial differed little between sediments in the range of $0.0625-2 \mathrm{~mm}$, but then increased sharply between 2 and $>4 \mathrm{~mm}$ (Fig. 6). For the large Emerita, only one pair of significant differences among sediment size classes smaller than $>4 \mathrm{~mm}$ emerged; burial times in natural beach sediments with median of $0.177 \mathrm{~mm}$ were shorter than those in 0.0625 and 2 $\mathrm{mm}$ sediments. For both small and large Emerita, burial time increased significantly between the smaller sediment size classes and the $>4 \mathrm{~mm}$ class (Fig. 6). Results for large Emerita also implied longer times to achieve burial in the smallest sediment size of $0.0625 \mathrm{~mm}$, but this average time was only significantly greater than that in the natural beach sediments. Like Donax, Emerita of larger body size buried themselves more slowly than the smaller animals (Fig. 6). Overall across all sediment sizes and for both size classes of invertebrates, burrowing rates of Emerita were about an order of magnitude more rapid than those of Donax. When large Emerita and Donax encountered relatively large shell fragments during their attempts at burial, they were often forced to reorient their digging.

In results of our dilution tests of impacts of changing mixtures of shell fragments from 2 to $>4 \mathrm{~mm}$ with natural beach sediments, mimicking any process that involved addition of coarse shell hash to natural beach sediments, Donax and Emerita exhibited similar but not identical responses (Fig. 7). Donax burrowing times to complete burial varied significantly in two-way ANOVA with clam size $\left(F_{1,170}=110.5, P\right.$ $<0.0001)$ and shell dilution ratio $\left(F_{5,170}=24.6, P<0.0001\right)$, but not with their interaction $\left(F_{1,2}=1.2, P=0.31\right)$. Emerita burial times varied with crab size $\left(F_{1,348}=82.7\right.$, $P<0.0001)$, shell dilution ratio $\left(F_{5,348}=99.5, P<0.0001\right)$, and their interaction $\left(F_{5,348}\right.$ $=7.4, P<0.001)$. The significant interaction effect demonstrated by Emerita burial 

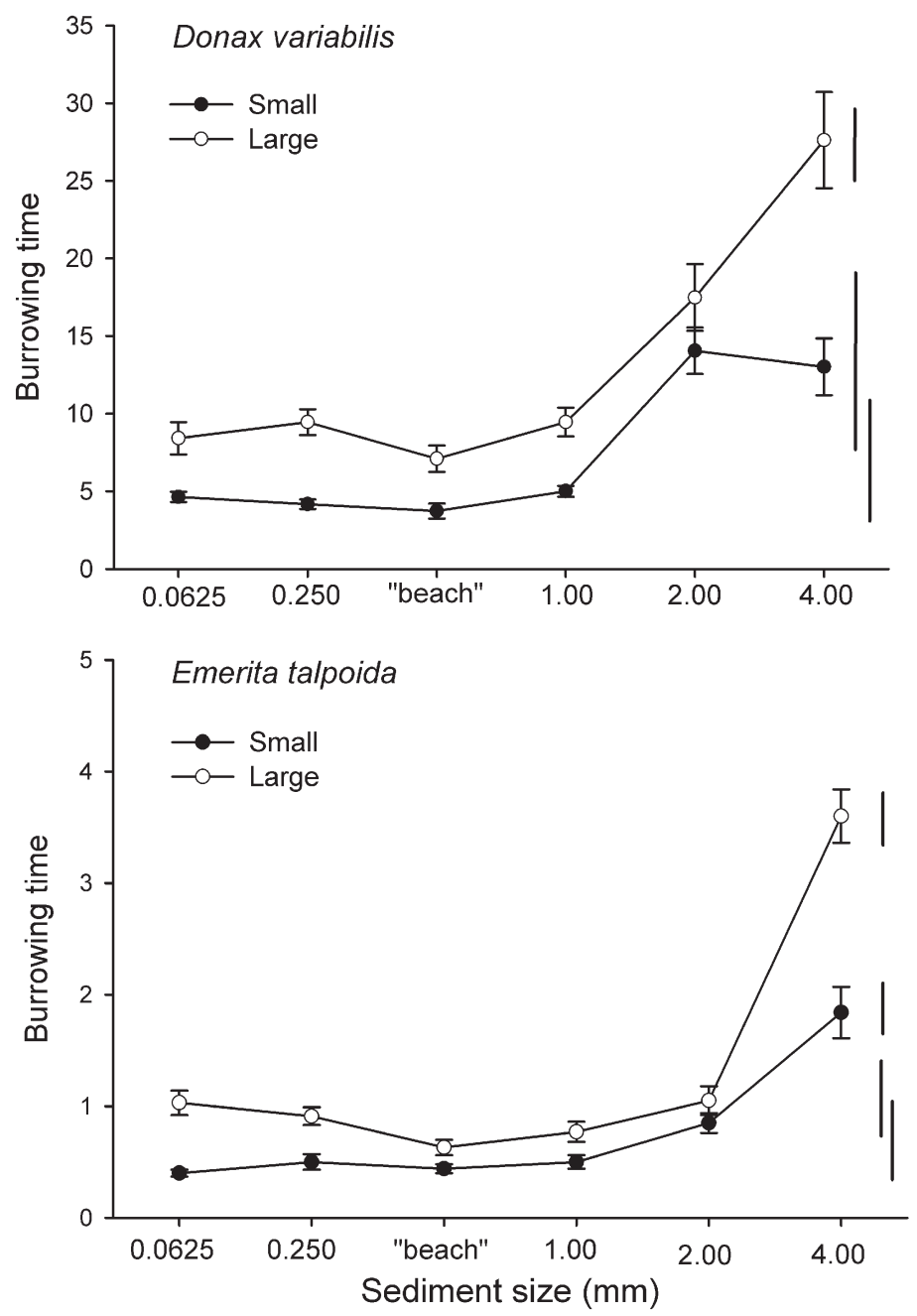

Figure 6. Mean (SE) burrowing times to complete burial for Donax variabilis and Emerita talpoida as a function of mean sediment size in sieve-sorted size classes plus the natural beach sand with mean particle size of $0.177 \mathrm{~mm}$. The vertical bars reflect results of Tukey a posteriori comparisons after two-way ANOVA revealed significance of the interaction between animal and sediment size classes.

rate does not appear to be particularly interesting (Fig. 7). For both species, burrowing time to complete burial increased progressively from a minimum time associated with the natural beach sands upward to longer times as volumetric ratio of natural beach sand to shell fragments was gradually modified from 4:1 to 1:4 (Fig. 7). The compelling pattern of progressively longer times required for burial as shell content increased emerged for both small and large individuals of Donax and Emerita. For both Donax and Emerita, the smaller individuals required less time to complete burial than the larger individuals in all sediment treatments (Fig. 7). Results of these dilution trials again revealed that time to complete burial is about an order of magnitude longer for Donax than for Emerita (Fig. 7).

Relationship between Shell Content of Swash-Zone Sediments and Donax Abundance on Natural Beaches.-The density of Donax spp. declined linearly with both increasing mean sediment size and increasing coarse shell content 

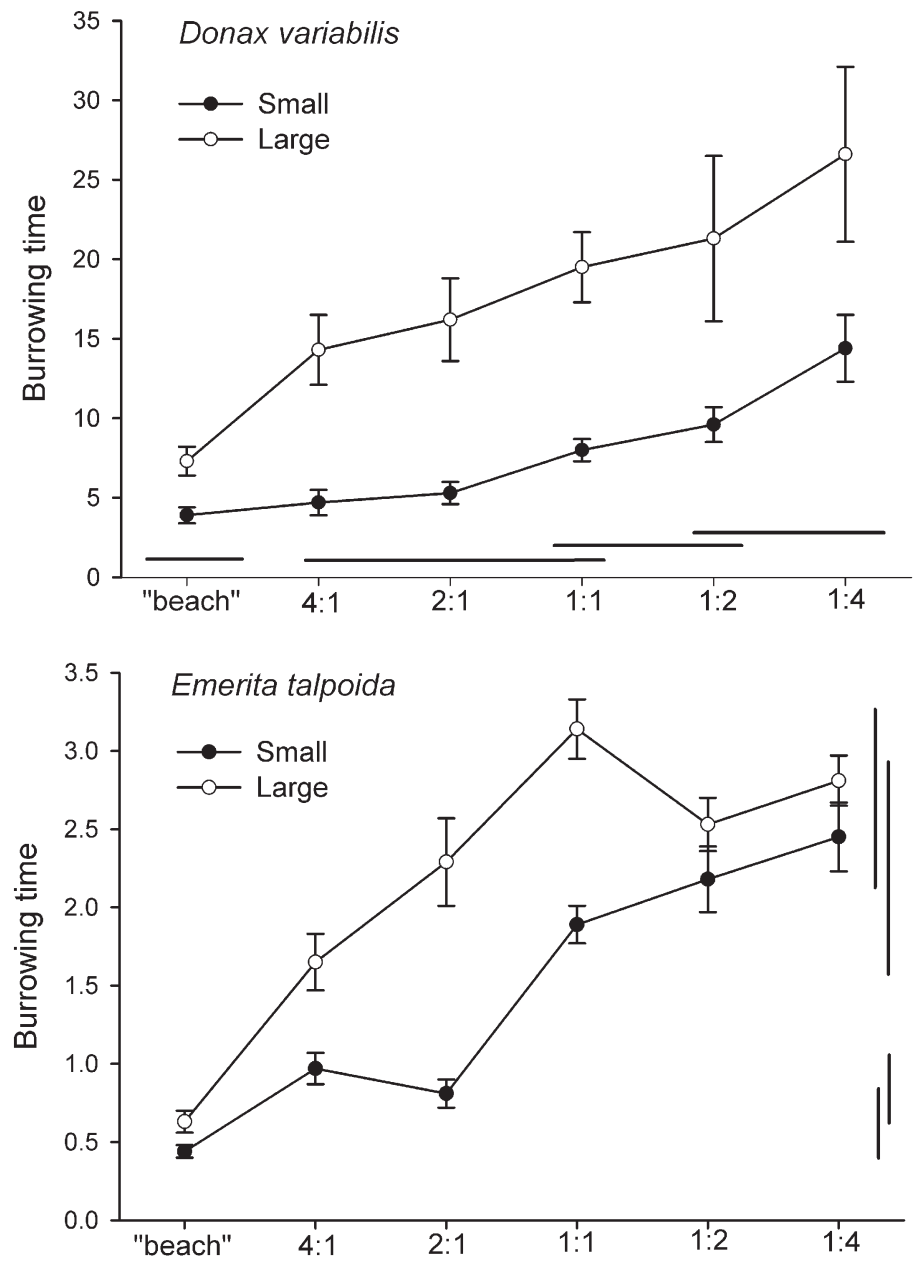

Sand:shell ratio

Figure 7. Mean (SE) burrowing times to complete burial for Donax variabilis and Emerita talpoida as a function of ratios (by volume) of sand (mean particle size of $0.177 \mathrm{~mm}$ ) to shell ( 2 to $>4$ $\mathrm{mm}$ ) and in 0.177-mm "beach" sand alone. Two-way ANOVA results indicated significance of both main factors (animal size class and sand:shell ratio) but no significant interaction for Donax. Significant differences among sand:shell ratio treatments are indicated by the nonoverlapping horizontal bars. Significant differences among Emerita means after a significant interaction in two-way ANOVA are indicated by vertical bars as in Figure 6 .

on the six beaches sampled on Shackleford Banks (Fig. 8). In the regressions, 78\%$86 \%$ of the variance among beaches was explained by the sedimentological independent variable. The intercept with the $x$-axis reflecting zero abundance of Donax fell at a mean sediment size of approximately $0.58 \mathrm{~mm}$ and a mean coarse shell content by weight of approximately $40 \%$.

Effects of Shell Content on Florida Pompano feeding Rates on DonaX In WaVe-Tank Mesocosms.-The augmentation of coarse shell fragments in sediments substantially reduced feeding rate of Florida pompano on Donax in the swash 

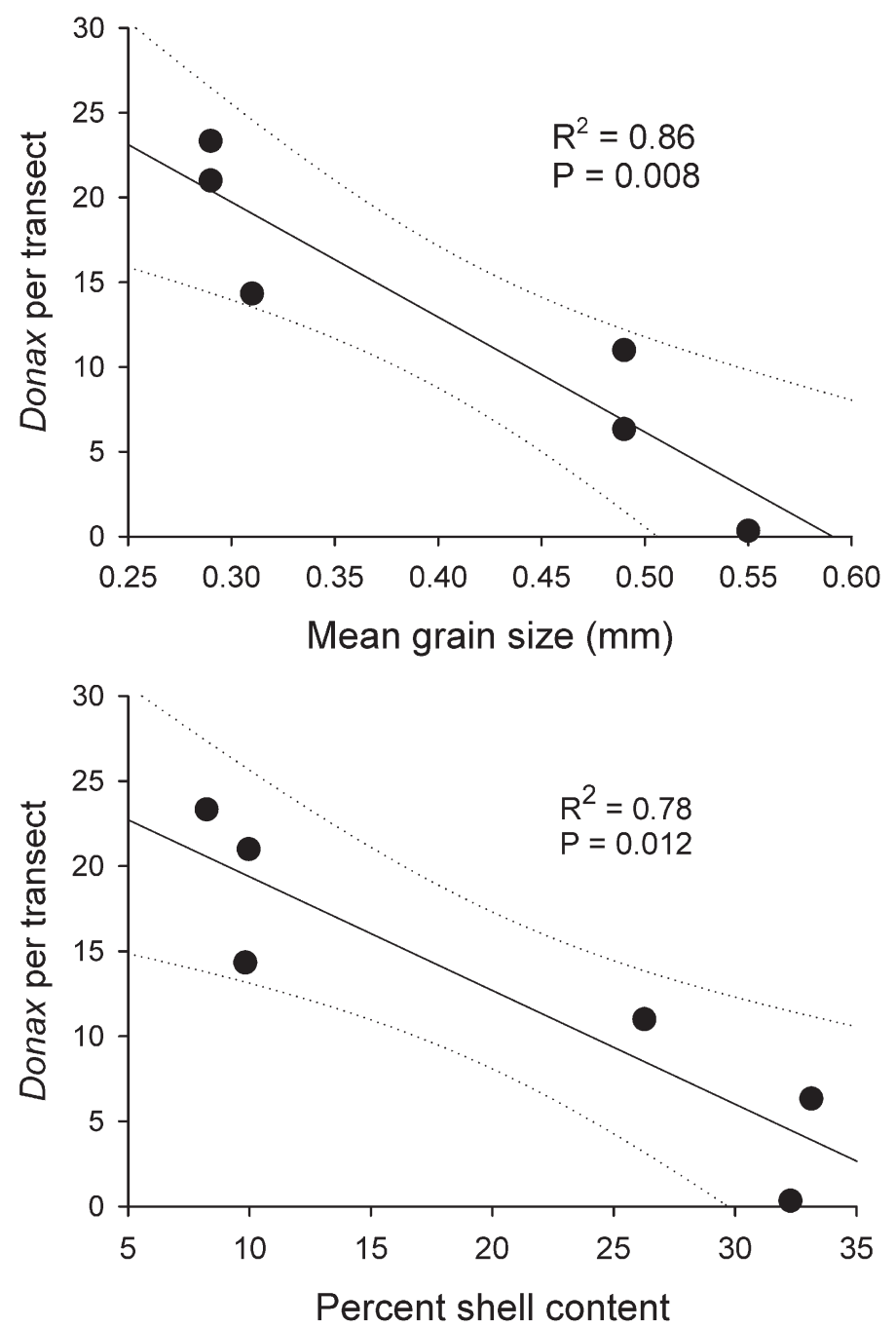

Figure 8. Relationships and results of linear regressions between Donax spp. density and mean grain size and percent shell content by weight from sampling of six beaches ranging over a $15-\mathrm{km}$ shoreline stretch of undeveloped and never nourished Shackleford Banks. Dotted lines indicate the $95 \%$ confidence limits for each regression.

zone of wave-tank mesocosms. In treatments in which the ratios of coarse shell to sediment were $1: 1$ and $2: 1$ by volume, feeding rate was reduced by over $50 \%$ from that on natural sandy-beach sediments (Fig. 9). A further $50 \%$ reduction at a shell:sand ratio of 4:1 was not detected as significant in a conservative post hoc contrast. We frequently observed pompano taking larger shell fragments into their mouths and then spitting them out.

Effects of Background Shell Color on Predator Preferences for Shell Color of DONAX PREY.-The two predators differed fundamentally in their responses to Donax prey on background shell fragments of matching and nonmatching color (Fig. 10). White Donax experienced significantly less predation by pompano 


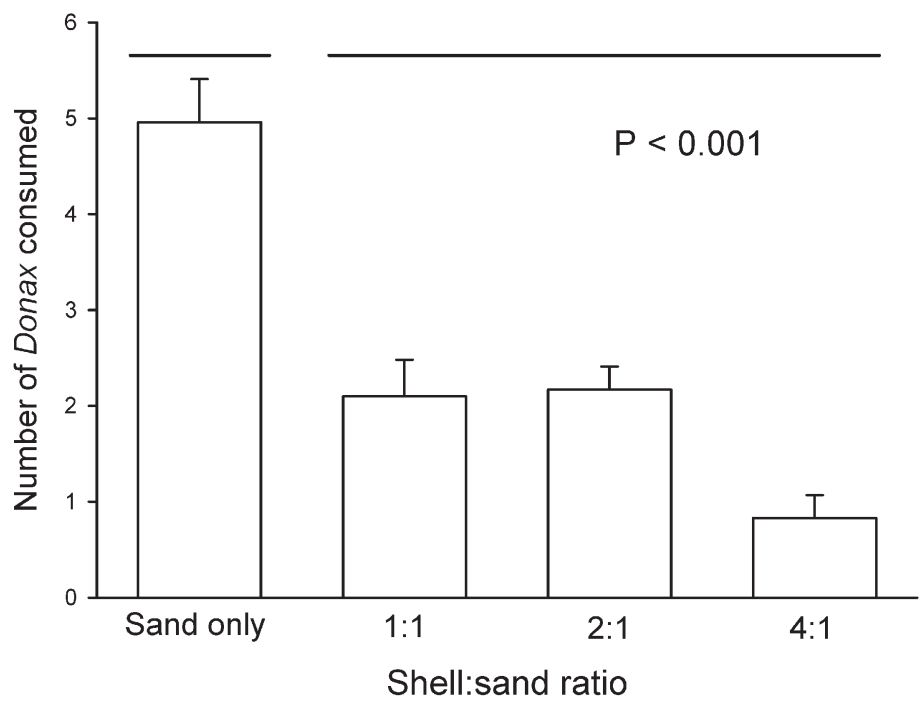

Figure 9. Effects of increasing shell content by volume on mean (SE, $n=8)$ feeding rate (consumptions per $5 \mathrm{~min}$ ) of pompano on Donax variabilis prey in wave-tank mesocosms. Nonoverlapping lines indicate significant differences among means resulting from a Scheffé post hoc contrast after a highly significant sediment effect in one-way ANOVA.

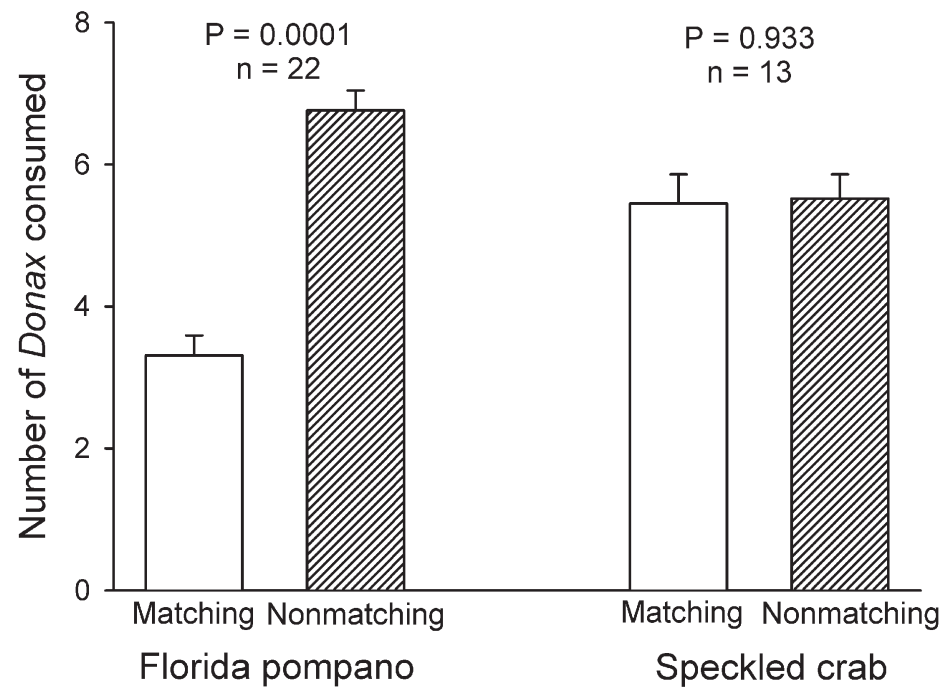

Figure 10. Mean (SE) consumption of prey in feeding trials in which Florida pompano and speckled crabs were offered Donax variabilis prey that did or did not match the color of shell fragments on the sediment surface. $P$-values derive from Poisson-based GLM. 


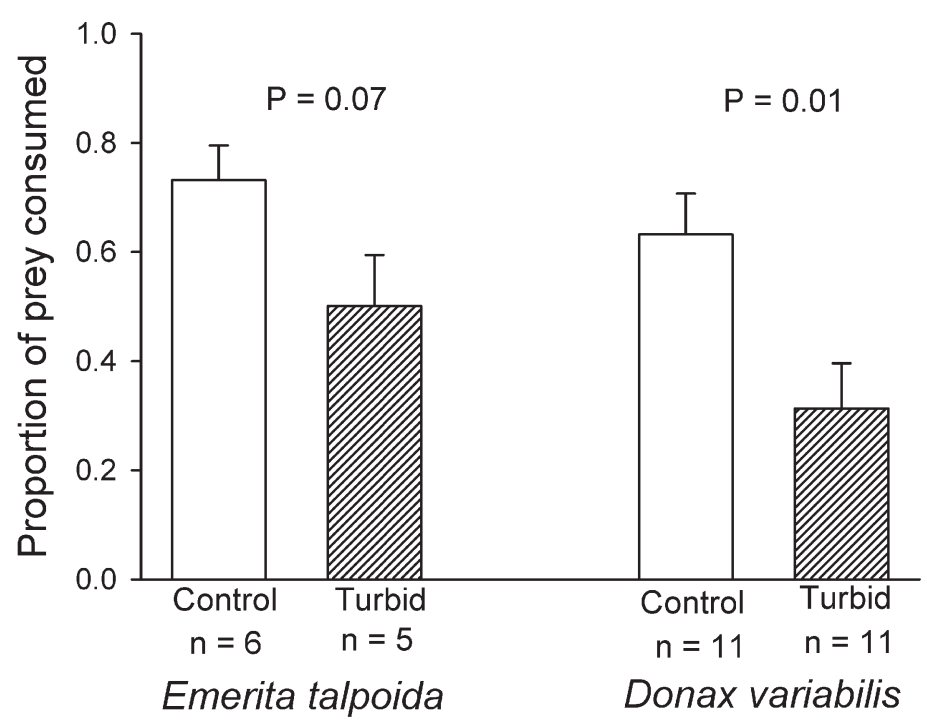

Figure 11. Mean (SE) numbers of prey consumed as a function of turbidity (7 and 74 NTUs for Emerita; and 9 and 101 NTUs for Donax) in wave-tank feeding trials with Florida pompano as predators. $P$-values derive from $t$-tests on arcsin-transformed proportions.

when the background of shell fragments was white than when it was medium gray. Similarly, grayish purple Donax experienced less predation when the background was medium gray than when it was white (results not shown). In sharp contrast, speckled crabs showed no indication of prey preference based on shell color relative to background (Fig. 10).

Wave-Tank Tests of Whether Turbidity Affects Predation Rate of POMPANO ON D. VARIABILIS AND E. TALPOIDA.- Under conditions of elevated turbidity, with NTUs similar to those detected months after completion of nourishment at nourished beaches subjected to onshore winds, pompano consumed both $D$. variabilis and E. talpoida at lower rates than under low turbidity (Fig. 11). The suppression of feeding on Donax was highly significant $40 \%$, whereas that on Emerita (25\%) was marginally nonsignificant. Replication of Emerita trials was only half that of Donax trials and contributed to a lower power to detect effects.

\section{Discussion}

Sand beaches on energetic ocean shorelines are exposed to physically rigorous conditions that have been shown repeatedly to dictate community composition of resident benthic macroinvertebrates and to result in their evolutionary adaptations to this environment. Wave and tidal energy combine to determine beach slope and sediment size and thereby influence abundance and diversity of the macrobenthos (Defeo and McLachlan 2005, McLachlan and Dorvlo 2005). Evolutionary adaptations in intertidal benthic organisms include rapid burrowing ability and swash-riding capability that allow many species of beach bivalves and mole crabs to migrate with rising and falling water levels and thereby sustain optimal feeding locations 
within the swash zone (McArdle and McLachlan 1992). Because of the obvious effects of physical factors on benthic community composition and on evolutionary adaptations of macrobenthos and the difficulty of conducting experiments on highenergy beaches, study of biological interactions has been limited and slow to develop. Among the most important roles of ocean sandy beaches is their service as habitat for nesting and foraging shorebirds, as feeding grounds for both demersal and pelagic surf fishes, and as nesting grounds for sea turtles (McLachlan and Erasmus 1983, Brown and McLachlan 1990). Predation therefore represents a critical biological process on sandy ocean beaches, so understanding the factors affecting foraging uses can be critical to protecting the functions and ecosystem services of sandy beaches as habitat.

Past research on biological interactions within ocean-beach habitats has focused primarily on factors influencing nesting success of sea turtles (because of their status as threatened or endangered species) and nesting and foraging success of shore- and seabirds (which can be readily studied by visual observation). Studies have revealed the critical effects of predation by humans, raccoons, red foxes, and ghost crabs on survival of sea-turtle eggs on ocean beaches (Bjorndal 1979). Other human modifications of the ocean-beach environment can dramatically affect reproductive success of sea turtles, including artificial lighting that disorients hatchlings and beach development that, as sea level rises, directly or indirectly eliminates the back-beach habitat necessary for nesting success. Studies of nesting success of shorebirds have likewise revealed the role of egg and nestling predation by mammals, birds, and snakes.

Sedimentary environment can influence feeding capability of shorebirds on tidal flats and, by extension, potentially also of demersal surf fishes on ocean beaches. Quammen (1982) sprinkled coarse sand on top of a mud-flat community of infaunal invertebrates that were serving as prey for a suite of shorebirds. The addition of a thin layer of coarse sand did not modify the density of invertebrate prey but did affect access to them, resulting in lower prey-capture success by several shorebird species followed by a decrease in use of this habitat compared to that of the unmodified control mud flat. Similarly, VanDusen et al. (UNC, Inst of Marine Sciences, unpubl data) took advantage of the ability to observe shorebird habitat use and demonstrated that probing shorebirds avoided feeding on one tidal flat characterized by surface shell hash despite a substantial abundance of infaunal prey. No such study has yet addressed how coarse, shell-rich sediments may degrade habitat value for demersal surf fishes, largely because visual observation of surf-fish feeding in the natural surf- and swash-zone beach habitats is so difficult. We therefore developed our novel wavetank mesocosm (Fig. 2) to reproduce the physical environment of oscillatory water flows and shoaling waves characteristic of the surf- and swash-zone habitats in which to conduct experimental tests of the effects of coarse shell content of sediments on behavior of both invertebrate prey and demersal fish feeding on them. Such information can help protect vital habitat for demersal surf fishes against degradation associated with beach nourishment and other human modifications (McLachlan 1996, Peterson et al. 2006). In addition, the wave-tank mesocosms facilitate experimental tests of how turbidity influences the ability of surf fishes to detect and capture prey.

Beach nourishment can degrade the intertidal and shallow subtidal foraging habitats for demersal surf fishes by three major processes: (1) inducing mass mortality of macrobenthic infaunal prey through rapid burial by up to $1 \mathrm{~m}$ or more of dredged fill materials; (2) modifying the sedimentology of these beach zones through filling with 


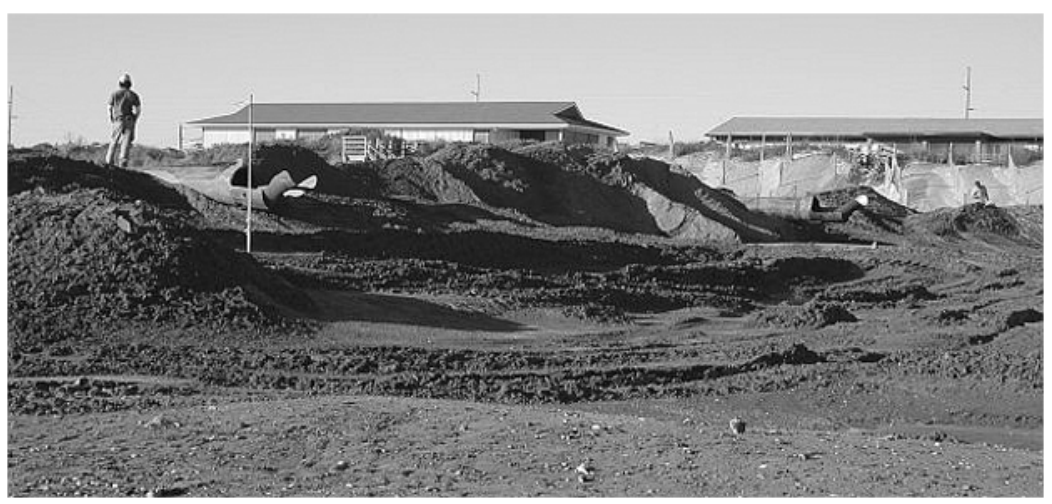

Figure 12. Photograph of ongoing beach nourishment during Phase I in Pine Knoll Shores on Bogue Banks, illustrating the vertical heights of dredged materials and their coarse, shelly nature, visible in the foreground.

excessive proportions of coarse, often shelly sediments that are incompatible with habitat requirements of some important benthic invertebrates, such as beach bivalves; and (3) incorporating into the beach fill excessive quantities of fine sediments in silt and clay sizes, which can induce higher near-shore turbidity during periods of erosion as onshore winds or distant storms generate wave action, thereby inhibiting detection of prey by visually orienting fishes. The first of these processes represents an unavoidable consequence of beach nourishment because the high costs of mobilizing dredges and equipment lead to conducting a few large-scale fill projects rather than numerous small beach fills. The opinion repeated in many environmental impact statements and environmental assessments that marine benthic invertebrates of ocean beach habitats are well adapted to surviving the sediment deposition of beach nourishment because of evolutionary experience with frequent erosion and deposition events associated with intense storms and high waves is unsupportable. A recent review of the literature on impacts of storms on ocean-beach macrofauna (Harris et al. 2011) reveals that about half the studies report massive reductions of beach infaunal populations after storms. Furthermore, the evolutionary experience of beach benthos with storms involves rapid erosion over hours to days during the storm followed by slow return of those sediments over months of calm conditions. In stark contrast, beach nourishment creates rapid sediment deposition of $1 \mathrm{~m}$ or more in periods of hours to days, accompanied by bulldozing (Fig. 12). Mass mortality typically follows immediately after beach filling (e.g., Peterson et al. 2000, 2006, Greene 2002). Nevertheless, recovery from this physical burial can be relatively rapid, within a year if the sedimentology of the fill matches natural beach sediments (and therefore acts as a pulse disturbance; Bender et al. 1984) and if the nourishment is conducted during winter (and therefore does not interfere with spring-summer recruitment of and colonization by infaunal invertebrates; Peterson and Bishop 2005).

The effects of inclusion of higher levels of coarse sediments, including shell hash, and of silts and clays than were present before nourishment may have long-term implications for recovery of the natural benthic invertebrate community. Coarse sediments are less readily eroded and could even increase in concentration after filling as finer materials are eroded and transported away. Addition of excessive coarse sediment could therefore represent a press disturbance (Bender et al. 1984) lasting for 
years. If those species that cannot tolerate the presence of coarse sediment include important prey for surf fishes, then beach foraging habitat could likewise be degraded for years. Excessive levels of fine sediments can be expected to be resuspended and transported into nearshore waters each time wave action is sufficient to create erosion scarps and erode into the fill. This disturbance could be considered recurrent pulse perturbations (Bender et al. 1984), lasting perhaps as long as the beachnourishment project, because progressive erosion into the sacrificial sediment mass would release newly exposed fine sediments at each erosion event.

Our multiyear sediment sampling on beaches nourished as part of the Phase I and Phase II Bogue Banks Nourishment Project revealed that elevated levels of coarse particles (in both gravel and coarse-sand sizes) persisted for at least the $2.5 \mathrm{yrs}$ of our study after nourishment. No indication of a trend toward convergence with control sedimentology was evident. In addition, the areal coverage of mid-intertidal and swash-zone sediments by surface shell remained elevated for at least $2.5 \mathrm{yrs}$, although this habitat modification showed evidence of some gradual progress toward convergence with control conditions.

Repeated sampling did not detect higher-than-normal quantities of fine (silt/clay) sediments beyond the summer of 2002, 4-8 mo after nourishment. The expected recurrent pulses of turbidity were therefore not evident over multiple years, but within that 4- to 8-mo summer period, we did detect such recurrent pulses in the near-shore ocean waters inside the sand bar on nourished beaches. The detectable difference between the near-shore $(0.5 \mathrm{~m})$ sampling station and the deeper one $(1.5 \mathrm{~m})$ is not surprising given that wave action striking the bottom is more intense in the surf zone, which presumably serves as the source for most turbidity within this broad slough between the beach and the sand bar. The effect of nourishment in this case was to reduce water clarity during wave events more, and for longer period, than occurred naturally and to sustain a longer violation of state water-quality standards. Pompano in our wave-tank experiment demonstrated a sensitivity to turbidity at around 70-100 NTUs, similar to levels detected along the Bogue Banks beach in response to erosive waves months after nourishment was completed. Feeding rates on both Donax and Emerita appeared dramatically reduced under elevated turbidity, although small sample size contributed to lack of significance for the latter. The implication of these results is that, during at least the first summer season after completion of the project, nourishment with only slightly elevated fine sediments periodically degraded the water-column habitat for visually orienting predators.

The persistence of elevated concentrations of coarse, shelly sediments has even more serious implications for degradation of critical feeding habitat for pompano and, by extension, other demersal surf fishes. First, because our 2.5-yr study did not detect even the beginning of convergence between the nourished and control beaches, the sedimentological changes probably persisted for years after our study period. Second, our field burrowing-rate trials demonstrated that burial by both $D$. variabilis and E. talpoida was much slower when coarse shell composition of surface sediments was elevated. Time to complete burial was greater for larger Donax and larger Emerita, and our burrowing-rate trials revealed that burial by larger individuals of both these invertebrates was particularly slow in the coarsest (pebble-sized) shell materials, in which they were frequently forced to re-orient their burrowing direction after encountering resistance from large shell fragments. Donax burrowing rates were a full order of magnitude lower than those of Emerita for every shell 
concentration, doubtlessly because digging with multiple appendages is so much more efficient than doing so with a bivalve foot (Stanley 1970). Sampling of unmodified beaches on Shackleford Banks revealed that the abundance of Donax spp. declined linearly with the coarse shell content of sediments. Donax abundance is predicted to fall to zero at a shell concentration of about $40 \%$ by weight, which is very close to the levels created by the Bogue Banks beach-nourishment project. In sampling to detect impacts of that project, Peterson et al. (2006) documented a precipitous decline in the Donax population after nourishment, which persisted without recovery for at least the entire year after completion of the project. We suggest that the depression of Donax abundance in coarse shelly sediments follows from their naturally slower burrowing and longer burial times in coarse sediments (Stanley 1970, Kranz 1976, Alexander et al. 1993, Nel et al. 2001, present study), which lead to their transport by waves off their swash-zone habitat and inability to feed during the outgoing wave swash because of insufficient time after complete burial (Nel et al. 2001). The decline in Donax density represents a serious drop in prey availability for pompano, because Donax biomass on unmodified control beaches dominates the macrobenthos and Emerita, despite its tolerance of coarse sediments (Bowman and Dolan 1985), did not demonstrate a compensatory increase on nourished Bogue Banks beaches (Peterson et al. 2006).

In addition to the steep decrease in abundance and biomass of their prey on Bogue Banks beaches after nourishment (Peterson et al. 2006), the pompano in our wavetank experiments fed less effectively on Donax in the presence of coarse surface shell fragments. Furthermore, as predicted for a visual predator, they fed preferentially on those Donax whose shell color contrasted with that of the shell fragments, whereas the speckled crab, A. cribrarius, a tactile and olfactory predator used as a control consumer, showed no color preference. Pompano feeding on Donax in the mesocosms were frequently observed to take surface shell fragments into their mouths even in the presence of living Donax prey, evidence of visual confusion. The shell hash deposited during beach nourishment therefore has direct negative effects on pompano feeding efficiency in addition to long-term impacts on abundance of an important prey species (Peterson et al. 2006).

The work reported here and studies by others have shown that beach nourishment as now practiced degrades the important swash-zone feeding habitat for both probing shorebirds (Quammen 1982; VanDusen et al., UNC, Inst of Marine Sciences, unpubl data) and demersal surf fishes (our study). This degradation could be avoided through adequate regulation of the choice of sediments used in beach filling. The United States Army Corps of Engineers has for many years regulated the percentage of fine sediments allowed in such fill, but the quantity allowed ( $10 \%$ by weight) vastly exceeds the fine content of most high-energy ocean beaches. Our demonstration here of periodic induction of turbidity events exceeding North Carolina waterquality standards on beaches where nourishment raised silt/clay content only from about $0.3 \%-0.6 \%$ to $0.6 \%-1.1 \%$ (Peterson et al. 2006) indicates that the $10 \%$ content allowed may be far too high. Our new results imply that even a $1 \%$ silt-clay allowance may fail to protect against periodic high, near-shore turbidity on beaches with naturally low concentrations of fine sediments, suppressing normal feeding rates not only of visually orienting demersal fishes like pompano but probably also pelagic surf fishes like bluefish, Pomatomus saltatrix (Linnaeus, 1766). 
Meanwhile, because no federal standard regulates coarse sediment during filling of ocean-beach habitat, this vital habitat receives no protection against the long-term degradation that arises from addition of coarse, shelly sediments to beaches at concentrations far above natural levels. Despite the Essential Fish Habitat protections provided by the Magnuson-Stevens Fisheries Conservation and Management Act, fishes for which the surf zone serves as a vital foraging habitat apparently do not enjoy adequate protection. Pompano are not federally managed despite their clear seasonal migrations across many states, perhaps because of their predominantly recreational use. The states are therefore left to protect vital swash habitat for pompano and other surf fishes. The coarse fill content used in the absence of regulation takes longer to erode away than would the medium-fine sands characteristic of undisturbed sandy beaches. Consequently, project engineers prefer to nourish with coarse sediments so as to produce more durable beach nourishment projects and save communities the high costs of frequent renourishment. Beach nourishment projects typically have short, 1-5-yr lifetimes (Leonard et al. 1990), but letting costs alone dictate project design leads to serious and long-term habitat degradation, to the detriment of beach invertebrates, shorebirds, and recreationally desirable surf fishes.

\section{ACKNOWLEDGMENTS}

Financial support was provided by North Carolina Sea Grant Mini-grants and a North Carolina Fisheries Resource Grant. We also acknowledge the DCERP environmental funding program of the US Department of Defense, which allowed us to prepare this paper for publication. G Johnson and L D'Anna helped conduct sediment sampling and process samples on Bogue Banks beaches and maintain databases. C Tallent, T Riley, J Grabowski, and H Summerson provided field and laboratory assistance. Reviews by O Defeo and an anonymous reviewer improved the manuscript. We appreciate encouragement from and the support of FC Coleman and the Mote Fisheries Symposia. AB Thistle provided exceptional editorial guidance.

\section{Literature Cited}

Alexander RR, Stanton RJ, Dodd JR. 1993. Influence of sediment grain size on the burrowing of bivalves: correlation with distribution and stratigraphic persistence of selected Neogene clams. Palaios. 8:289-303. http://dx.doi.org/10.2307/3515151

Bender EA, Case TJ, Gilpin ME. 1984. Perturbation experiments in community ecology: theory and practice. Ecology. 65:1-13. http://dx.doi.org/10.2307/1939452

Bjorndal KA, editor. 1979. Biology and conservation of sea turtles. Washington: Smithsonian Institution.

Bowman ML, Dolan R. 1985. The relationship of Emerita talpoida to beach characteristics. J Coast Res. 1:151-163.

Brown AC, McLachlan A. 1990. Ecology of sandy shores. Amsterdam: Elsevier.

Day RW, Quinn JP. 1989. Comparisons of treatments after an analysis of variance in ecology. Ecol Monogr. 59:433-463. http://dx.doi.org/10.2307/1943075

Defeo O, McLachlan A. 2005. Patterns, processes and regulatory mechanisms in sandy beach macrofauna: a multi-scale analysis. Mar Ecol Prog Ser. 295:1-20. http://dx.doi.org/10.3354/ meps 295001

Defeo O, McLachlan A, Schoeman DS, Schlacher TA, Dugan J, Jones A, Lastra M, Scapini F. 2009. Threats to sandy beach ecosystems: a review. Estuar Coast Shelf Sci. 81:1-12. http:// dx.doi.org/10.1016/j.ecss.2008.09.022 
Dugan JE, Defeo O, Jaramillo E, Jones AR, Lastra M, Nel R, Peterson CH, Scapinin F, Schlacher TA, Schoeman DS. 2010. Give beach ecosystems their day in the sun. Science. 329:1146. PMid:20813935. http://dx.doi.org/10.1126/science.329.5996.1146-a

Greene K. 2002. Beach nourishment: a review of the biological and physical impacts. ASMFC Habitat Management Series no. 7. Washington, DC: Atlantic States Marine Fisheries Commission.

Harris L, Nel R, Smale M, Schoeman D. 2011. Swashed away? Storm impacts on sandy beach macrofaunal communities. Estuar Coast Shelf Sci. 94:210-221. http://dx.doi.org/10.1016/j. ecss.2011.06.013

James RJ, Fairweather PG. 1996. Spatial variation of intertidal macrofauna on a sandy ocean beach in Australia. Estuar Coast Shelf Sci. 43:81-107. http://dx.doi.org/10.1006/ ecss.1996.0058

Johnson RG. 1971. Animal-sediment relations in shallow-water benthic communities. Mar Geol. 11:93-104. http://dx.doi.org/10.1016/0025-3227(71)90069-7

Kranz PM. 1976. Anastrophic burial of bivalves and its paleoecological significance. J Geol. 82:237-265. http://dx.doi.org/10.1086/627961

Leber KM. 1982. Seasonality of macroinvertebrates on a temperate high wave energy sand beach. Bull Mar Sci. 32:86-98.

Leonard L, Clayton T, Pilkey O. 1990. An analysis of replenished beach design parameters on US East Coast barrier islands. J Coast Res. 6:15-36.

Manning LM. 2003. Ecology of ocean beaches: the importance of human disturbances and complex biological interactions within a physically rigorous environment. PhD dissertation. University of North Carolina, Chapel Hill, NC.

McArdle SB, McLachlan A. 1992. Sand beach ecology: swash features relevant to the macrofauna. J Coast Res. 8:398-407.

McLachlan A. 1996. Physical factors in benthic ecology: effects of changing sand particle size on beach fauna. Mar Ecol Prog Ser. 131:205-217. http://dx.doi.org/10.3354/meps131205

McLachlan A, Dorvlo A. 2005. Global patterns in sandy beach macrobenthic communities. J Coast Res. 21:674-687. http://dx.doi.org/10.2112/03-0114.1

McLachlan A, Erasmus T, editors. 1983. Sandy beaches as ecosystems. The Hague: W Junk.

Nel R, McLachlan A, Winter DPE. 2001. The effect of grain size on the burrowing of two Donax species. J Exp Mar Biol Ecol. 265:219-238. http://dx.doi.org/10.1016/ S0022-0981(01)00335-5

Peterson CH, Bishop MJ. 2005. Assessing the environmental impacts of beach nourishment. BioScience. 55:887-896. http://dx.doi.org/10.1641/0006-3568(2005)055[0887:ATEIOB]2.0 .CO;2

Peterson CH, Summerson HC, Thomson E, Lenihan HS, Grabowski J, Manning L, Michelli F, Johnson G. 2000. Synthesis of linkages between benthic and fish communities as a key to protecting essential fish habitat. Bull Mar Sci. 66:759-774.

Peterson CH, Bishop MJ, Johnson GA, D’Anna LM, Manning LM. 2006. Exploiting beach filling as an unaffordable experiment: benthic intertidal impacts propagating upwards to shorebirds. J Exp Mar Biol Ecol. 338:205-221. http://dx.doi.org/10.1016/j.jembe.2006.06.021

Quammen ML. 1982. Influence of subtle substrate differences on feeding shorebirds on intertidal mudflats. Mar Biol. 75:339-343. http://dx.doi.org/10.1007/BF00397050

Rhoads DC, DK Young. 1970. Influence of deposit-feeding organisms on sediment stability and community trophic structure. J Mar Res. 28:150-178.

Sanders HL. 1958. Benthic studies in Buzzards Bay 1. Animal-sediment relationships. Limnol Oceanogr. 3:245-258. http://dx.doi.org/10.4319/lo.1958.3.3.0245

Schlacher TA, Schoeman DS, Dugan J, Lastra M, Jones A, Scapini F, McLachlan A. 2008. Sandy beach ecosystems: key features, sampling issues, management challenges and climate change impacts. Mar Ecol. 29:70-90. http://dx.doi.org/10.1111/j.1439-0485.2007.00204.x

Snelgrove PVR, Butman CA. 1994. Animal-sediment relationships revisited-cause versus effect. Oceanogr Mar Biol Annu Rev. 32:111-177. 
Stanley SM. 1970. Relation of shell form to life habits of the Bivalvia (Mollusca). Geological Society of America Memoir 125. Boulder, CO: Geological Society of America.

Date Submitted: 23 January, 2012.

DATE ACCEPTED: 19 June, 2012.

Available Online: 8 October, 2012.

Addresses: (LMM) NOAA, 1315 East-West Highway, SSMC3, Silver Spring, Maryland 20910. (CHP, SRF) University of North Carolina at Chapel Hill, Institute of Marine Sciences, 3431 Arendell Street, Morehead City, North Carolina 28557. Corresponding Author: (CHP) Email: <cpeters@email.unc.edu>.

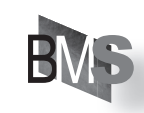

